\section{Asbestos-related cancers in Brazil}

\author{
Cânceres relacionados ao asbesto no Brasil
}

\author{
Cánceres relacionados con el asbesto en Brasil
}

Since Brazil is a major producer, consumer and exporter of asbestos, monitoring the occurrence of asbestos-related diseases is crucial. Whereas other asbestos-related cancers are multifactorial in origin, the major risk factor for mesothelioma is asbestos. In many countries, the occurrence of this malignancy in the population reflects the use of asbestos in the economy. In Brazil, nevertheless, data on mesothelioma are limited and their quality has not been verified. Mortality from mesothelioma (C45 in the 10th revision of the International Classification of Diseases - ICD-10) and from pleural cancer (C38.4) in 1980-2010 has been described 1 but incidence data provided by Brazilian Population Based Cancer Registries (PBCR) have received little attention.

Data from the PBCR are collected in a public domain databank: SisBasepop ${ }^{2}$. Six of them exhibited adequate quality criteria for inclusion in the latest update 3 of Cancer Incidence in 5 Continents (CI5). These cover residents in the cities of Aracaju, Belo Horizonte, Cuiabá, Fortaleza, Goiania and São Paulo, with an overall population of 17.9 million (less than $10 \%$ of the total population of the country). According to CI5, in 2003-2007, the pool of these registries collected a total of 82 cases of mesothelioma (51 men and 31 women) and 59 cases of cancer of the pleura not specified as mesotheliomas (35 men and 24 women). Around $75 \%$ of cases were collected by
Benedetto Terracini 1 Francisco Pedra 2 Ubirani Otero ${ }^{3}$

the São Paulo city PBCR, the largest in the country. For both mesotheliomas and other pleural cancers, all annual rates (age-standardized on the world population; ASR) are less than 2 per million inhabitants. For the sake of comparison, corresponding rates for mesothelioma in the pool of Italian Cancer Registries were 18.4 in men and 5.1 in women, whereas rates for pleural cancer were respectively 2.3 and 0.9 (Crocetti E. Letter to Benedetto Terracini, 03/Feb/2015). In Brazilian registries, $89 \%$ of mesotheliomas and $80 \%$ of pleural cancers were histologically confirmed, and $11 \%$ and $7 \%$ were Death Certificates (DC) only ${ }^{3}$. Histologically verified cases in Italy were $97 \%$ and $35 \%$ while DC only were $0.1 \%$ and 8\% (Crocetti E. Letter to Benedetto Terracini, 03/ Feb/2015).

Thus, the available data provide some information on the probability for a registered case to be a "false positive". The sensitivity of Brazilian cancer registries in the detection of mesothelioma cases (i.e. the complementary to "false negatives") is more difficult to estimate. C38.4 cancers are problematic. A French study has estimated that $86 \%$ of "pleural cancers" were in fact mesothelioma 4. Similar findings were obtained from a study in the UK 5 . It is reasonable to believe that this also happens in Brazil. International comparisons on the burden of asbestos-induced cancer have considered jointly C38-4 and C45 6. In- 
cidentally, according to the files of the PBCR, the number of cases coded as C38.4 exceeds those included in CI5 2.

A noteworthy finding of the Cancer Registry of São Paulo regards cancer of the mediastinum (C38.1-3), for which ASRs of 5 and 3 per million have been estimated in men and women. These rates are based on 122 and 81 cases and are therefore statistically stable. Worldwide, they rate are among the highest: for instance, they are twice as high as in the Italian pool (respectively 2.9 and 1.3). In São Paulo, however, the quality of data is debatable: only $38 \%$ of cases were histologically confirmed and $30 \%$ were DC only $(60 \%$ and $5 \%$ in Italy). Given the vicinity of the mediastinum and the pleura, there is a need for verifying the origin of these neoplasms.

Thus, for the time being, any estimate of incidence rates of mesotheliomas and pleural cancer and their time trends in Brazil is hardly more than a guess. With the exception of São Paulo, the Brazilian cancer registries overlap only to a limited extent with the geographical areas characterized by asbestos-related industrial activities. Massive industrial use of asbestos in Brazil started around 1975, decades later than in North America and Europe 7. The time elapsed to 2007 is short compared to latent periods of mesotheliomas re-

\section{Contributors}

All authors participated to the formulation of the project, data collection, drafting, revision and final approval of the manuscript. corded in epidemiological studies. Contrary to other recently industrialized countries (eg. Mexico), Brazil has imported negligible amounts of amphiboles from South Africa: virtually all asbestos used in Brazil has been chrysotile 8 . Mesotheliomas in Brazilian workers exposed to asbestos 9 confirm the ability of chrysotile to induce mesotheliomas, as stated by International Agency for Research on Cancer (IARC) 10.

MEDLINE does not record any analytical epidemiological (either case-control or occupational cohort) study carried out in Brazil on the association between asbestos and mesothelioma. The association with lung cancer has been investigated in one study only, carried out early after the expansion of industrial asbestos use 11 .

In conclusion, unravelling the measure of the carcinogenic effects of asbestos in Brazil requires an assessment of the extent of underdiagnosis and underregistration of mesothelioma cases. In addition, whereas the carcinogenicity of chrysotile is out of discussion 10 , analytical epidemiological methods should be applied in order to quantify the damage caused by this hazard in Brazil. Excluding construction activities, workers exposed to asbestos in Brazil have been grossly estimated to be about 74,000 12 .

\section{Acknowledgments}

Authors are grateful to the Italian Association of Cancer Registries, in the person of Dr. Emanuele Crocetti, for tabulations prepared ad hoc for the present paper. 
1. Pedra F, Silva P, Mattos I, Castro H. Mesothelioma mortality rate in Brazil, 1980 to 2010. Rev Bras Cancerol 2014; 60:199-206.

2. Instituto Nacional de Cancer José Alencar da Silva SisBasepop registros de câncer de base populacional. Rio de Janeiro: Instituto Nacional de Cance José Alencar da Silva. http://www2.inca.gov.br/ wps/wcm/connect/estatisticas/site/home/rcbp/ (accessed on 17/Dec/2014).

3. Forman D, Bray F, Brewster DH, Gombe Mbalawa C, Kohler B, Piñeros M, et al. Cancer incidence in five continents. v. X. Lyon: International Agency for Research on Cancer; 2014. (IARC Scientific Publications, 164).

4. Le Stang N, Belot A, Gilg Soit Ilg A, Rolland P, Astoul P, Bara S, et al. Evolution of pleural cancers and malignant pleural mesothelioma incidence in France between 1980 and 2005. Int J Cancer 2010; 126:232-8.

5. Harding AH, Darnton AJ. Asbestosis and mesothelioma among British asbestos workers (19712005). Am J Ind Med 2010; 53:1070-80.

6. Park EK, Takahashi K, Hoshuyama T, Cheng TJ, Delgermaa V, Le GV, et al. Global magnitude of reported and unreported mesothelioma. Environ Health Perspect 2011; 119:514-8.

7. Virta RL. Worldwide asbestos supply and consumption trends from 1900 through 2003. http:// pubs.usgs.gov/circ/2006/1298/ (accessed on 11/ Feb/2015).

8. Harington JS, McGlashan ND, Chelkowska EZ. South Africa's export trade in asbestos: demise of an industry. Am J Ind Med 2010; 53:524-34.
9. Algranti E. Audiência Pública Amianto - Eduardo Algranti. http://www.fundacentro.gov.br/multi midia/detalhe-do-video/2012/12/audiencia-pu blica-amianto-eduardo-algranti (accessed on 17/ Sep/2014).

10. International Agency for Research on Cancer. Asbestos, (chrysotile, mosite, crocidolite, tremolite, actinolite, and anthophyllite). In: International Agency for Research on Cancer, editor. Metals, arsenic, dusts and fibres. A review of human carcinogens. Lyon: International Agency for Research on Cancer; 2012. p. 219-309. (Monograph on the Evaluation of Carcinogenic Risks to Humans, 100C).

11. Wünsch-Filho V, Moncau JE, Mirabelli D, Boffetta P. Occupational risk factors of lung cancer in São Paulo, Brazil. Scand J Work Environ Health 1998; 24:118-24.

12. Departamento da Indústria da Construção, Federação das Indústrias do Estado de São Paulo. O papel dos produtos de amianto na cadeia da construção civil. Dimensão econômica e efeitos concorrenciais. http://www.fiesp.com.br/indices-pesquisas-e-publicacoes/o-papel-dos-produtos-de-amianto-na-cadeia-da-construcao-civil-as pectos-relevantes-da-dimensao-economica-dacadeia-dos-produtos-de-amianto/ (accessed on 26/Jun/2014).

Submitted on $25 / \mathrm{Feb} / 2015$

Approved on 16/Mar/2015 